\title{
Germany and the Janus Face of Immigration Federalism: Devolution vs. Centralization
}

\author{
Dagmar Soennecken
}

\begin{abstract}
What challenges and opportunities has federalism held for countries like Germany, one of Europe's most 'reluctant' states of immigration? Although the formal, constitutional division of powers between the German central government (Bund) and the federal states (Länder) has certainly shaped Germany's response to immigration and integration, federalism is only one aspect of a broader, 'semisovereign' model of governance that has dominated German state-society relations for decades (Katzenstein 1987). This model sees a range of decentralized state actors, among them constantly negotiating with a set of highly centralized societal (or "parapublic") organizations, such as churches, labour and employer associations, leading to at best incremental policy change over the years. While some observers argue that this model will endure and likely also impair Germany's ability to successfully navigate future immigration and integration challenges (Green and Paterson 2005), others argue that German political actors have been quite successful all along in shifting "venues" to suit their policy preferences, be that "up" (to the intergovernmental/EU level), "down" (to the local level) or "out" (to non-state actors) (Guiraudon and Lahav 2000). The chapter will argue that Germany's particular version of immigration federalism has facilitated both incrementalism and venue shifting.
\end{abstract}

Keywords Immigration federalism - Decentralization vs. centralization • Immigration enforcement $\bullet$ Naturalization $\bullet$ Asylum policies $\bullet$ Venue shifting • Germany

\subsection{Introduction}

The rapid expansion of the provincial nominee programs (PNPs) in Canada and attempts by an increasing number of American states to participate in determining immigrant rights and enforcing immigration regulations are examples of an emerging

\footnotetext{
D. Soennecken $(\triangle)$

School of Public Policy \& Administration (SPPA) \& Department of Social Science

(Law \& Society Program), York University, 136 McLaughlin College, 4700 Keele Street,

M3J 1P3, Toronto, ON, Canada

e-mail: dsoennec@yorku.ca
} 
trend in settler societies like the United States and Canada, where immigration matters have traditionally been the exclusive domain of the federal government. This trend has been referred to as "immigration federalism." It denotes the increasing role of subnational actors in the governance of immigration (Spiro 2001). A number of scholars consider this development to be reflective of a broader shift towards a neoliberal, "marketized" governance of immigration that promotes subnational and even private actors as being better suited to ensure the economic competitiveness of would-be immigrants in the global "battle for brains" (Shachar 2006). This realignment and "rescaling" of admission policies has been accompanied by another trend, namely the devolution of membership, which has seen the empowerment of subnational actors in the enforcement and definition of status and rights, along with the benefits to which noncitizens are entitled, with the goal of excluding those who do not fit the neoliberal logic (Varsanyi 2008).

How well does the "immigration federalism" concept travel to European societies such as Germany that have not traditionally defined themselves as countries of immigration? Is the marketization of immigration policy happening (and becoming problematic) there as well? And does it express itself there in the same way, namely through the rescaling and devolution of admission and membership? As this chapter will show, at first glance, Germany, one of Europe's largest immigrant societies, appears to be an outlier or a "very different" case. Three differences in particular stand out. First, subnational actors have played a prominent role in the governance of German immigration matters early on, ranging from enforcement to integration. Second, no formal devolution in the role of subnational actors seems to have taken place. Still, a number of shifts can be observed. Overall, we can observe a centralization trend.

This chapter argues that it is precisely the deliberate shifting of policy-making levels that is indicative of the efforts of nation-states to continuously adapt and reconstitute themselves in the age of neoliberalism. In short, both devolution and centralization are but two sides of the same phenomenon. As Guiraudon explains, since the beginning of the 1980s, European governments have deliberately used a wide array of actors to overcome growing domestic judicial obstacles and international human rights norms to remain in control of who enters, remains and belongs (Guiraudon 2000) by shifting "venues"- - either "up" to intergovernmental fora, "down" to local authorities or "out" to private actors such as air carriers. As Varsanyi concludes, "the neoliberal...state is not less powerful as much as it...organizes and rationalizes its interventions in different ways" (Varsanyi 2008, pp. 881-882).

The remainder of this chapter is divided into three parts. The first begins by discussing the general workings of German federalism. It highlights four factors that illustrate a general tendency towards coordination, joint decision making and power sharing that go much deeper than is common in (for instance) the US model (Scharpf 1988, p. 243): the significance of the Bundesrat, the implementation power of the Länder, the fiscal set-up and the limited options for acting alone. The subsequent section shows that all of these factors also shape the "multi-level" governance of immigration matters and that, in fact, the substantial involvement of subnational actors in the governance of immigration matters is a reflection of (and at times, a struggle with) this larger federal logic. 
The section opens with a brief review of Germany's population make-up, outlines its three migratory "waves" and then continues with a historical (albeit select) examination of labour migration and family reunification, asylum, enforcement and integration. In the areas of asylum and enforcement, deliberate shifts of responsibility between different levels of government took place in the mid 1970s and 1990s respectively with the goal of deterring and excluding noncitizens. In the area of labour migration, Germany was a pioneer of the marketization of immigrants through the employment of a guest worker scheme from the 1950s to 1973. Here, the constant federal-state level struggle over the setting of limits on residency permits and family reunification illustrates the deep involvement and discretion of subnational actors in defining questions of belonging and right to stay early on.

In contrast, integration policy was largely left to the subnational level until the late 1990s. First local experiments took place in the absence of any acceptance of permanent immigration at the federal level. However, more recently, labour migration and integration have been strongly centralized beginning with the reform of Germany's citizenship law (Staatsangehörigkeitsgesetz) in 1999 and the passing of the Migration Act (Zuwanderungsgesetz) in 2005. Residency categories and naturalization procedures have been simplified and subnational discretion reduced. At the same time, the federal level has asserted itself in the area of integration by passing new regulations and by similarly reducing discretion at the subnational level. Although many of these measures were passed in consultation with the subnational level, they - together with the steady stream of EU regulations concerning migration - all add up to a recent, centralization trend. In the conclusion, I briefly sum up the findings regarding the compatibility of the German case with the general trend outlined above.

The chapter uses historic analysis throughout to isolate and contrast different phases and important turning points (Pierson 2004). This approach is also helpful for comparative purposes as it underlines the constructed and fluctuating nature of federal power over immigration across federations. As Neuman's work has shown, the solidification of the US federal government's power over immigration and naturalization only took place after a decade during which the American states controlled significant aspects of immigration policy (Neuman 1996). The analysis of the German cases presented here spans the 1950s to the present. Important historical markers include the 1973 oil crisis (which ended Germany's guest worker programs), reunification in 1989 and Germany's first migration act in 2005.

\subsection{Federalism, Semi-Sovereignty and Multi-level Governance in Germany}

While Germany's postwar immigration history has been frequently analyzed, the role of subnational actors - the German states (Länder) and the over 2,000 cities and 11,000 municipalities (Gemeinden) (Thränhardt 2001, p. 26) - has been less frequently studied. Formally, immigration matters are federal jurisdiction (Art. 73, para 1 , no. $3 \mathrm{GG}$ ), while all residency matters of "aliens" or foreigners and issues concerning refugees are areas of "concurrent" jurisdiction (Art. 74, para 1 no. 4 and 6 GG) 
that are shared between the federal and state levels. The local level is not mentioned, although its independence is constitutionally protected (Art. 28 no. 2 GG).

At first glance, this division of labour makes it seem as if Germany fits the traditional US view that "immigration law" is exclusively federal jurisdiction because it is concerned with the admission and expulsion of aliens, which are matters at the heart of national sovereignty and foreign affairs, in contrast to "alienage" or foreigner laws (i.e. "other matters relating to their legal status"), including access to welfare and education - which are traditionally thought of as state-level jurisdiction (Motomura 1994, p. 202). ${ }^{1}$ However, the actual governance of immigration policy is far less clear cut and fairly consistent with the larger "unitary" German federalism, which grants subnational actors an important role in federal decision-making. It is this model we need to examine next before we can turn to the governance of immigration in more detail.

Although most observers would note that Germany has a long history of federalism, the contemporary model of German federalism laid out in the 1949 Basic Law was selected as a way to curb the power of the then highly centralized post-Nazi state (Erk 2008, p. 58). Thus, the initial post-war constitution envisioned a fairly decentralized federation with clear jurisdictional demarcations for federal versus Länder governments. However, over time, Germany-largely with the help of the Constitutional Court, a set of national policies for officially state-level competences, and a financial system that fosters dependence on the Bund (the federal level) - has developed strong centralizing tendencies and gradually evolved into a prime model of what some call "unitary" federalism (Gunlicks 2003, pp. 68-69) — so much so that a recent OECD report called on the federal government to more actively foster greater competition among states (Bendel and Sturm 2010, p. 175). ${ }^{2}$ A more fitting term perhaps is "interlocking" federalism. It highlights the fact that the institutional set-up of the system fosters such complex and multiple linkages between political actors at all levels of government, that one cannot effectively function without the participation of the others, to the extent that actors are frequently in a "joint decision making trap," which leads them to avoid confrontation, wait for agreement and accept sub-optimal outcomes for the sake of preserving unanimity (Scharpf 1988).

German federalism is characterized by such a high degree of unanimity, coordination and joint decision making that it is indeed difficult to find policy areas that are untouched by federal-state "harmonization" efforts, even those that are exclusive Land jurisdiction, such as education and culture. Despite recent federalism reforms in 2006 and 2009 that were aimed at clarifying jurisdictional and financial responsibilities, this fundamental pattern of decision-making has not changed.

What are the reasons for the high degree of cooperation in the German federation?

\footnotetext{
${ }^{1}$ As Motomura rightly notes, this legal division is in fact an artificial one that blurs the strong functional overlap between the two categories and their real, interlocking public policy consequences (Motomura 1994).

${ }^{2}$ The Länder have certainly taken the OECD up on the recommendation and now maintain separate representations in Brussels.
} 
First, Germany - a parliamentary republic with a President as the largely ceremonial head of state - allows for a substantial degree of state-level involvement in federal policy making. While the Bundestag is Germany's primary legislative venue, as well as the seat of the roughly 598 nationally elected members of parliament (who also elect the Chancellor, or head of government), the Bundesrat, Germany's second constitutional chamber, is an assembly of the states. It is primarily responsible for reviewing federal bills and regulations, although it can also introduce bills of its own. The Länder are represented in the Bundesrat by their Premier (Minister Präsident), and a number of ministers. However, all representatives from a given state have to vote unanimously. Voting power is assigned according to the size of a state's population, ranging from 3 to 6 votes (Art. $51 \mathrm{GG}$ ). States have a formal say over federal legislation if the bill in question is a matter of shared jurisdiction ("consent bills"; which represent circa 50 percent of all bills) or if it would impose significant costs on an individual state. States can also veto other laws not directly affecting them, although a majority of the Bundestag may subsequently overturn their veto. Until reunification, voting blocks in the Bundesrat used to mirror the typical federal government-opposition pattern and frequently lead to deadlocks, requiring resolution through a joint mediation committee (Art. 53 a GG) (Oeter 2006, p. 145). However since reunification, the pattern has been much less clear-cut. Knowing how to navigate within this environment is important, since the federal government's ability to pass legislation and pursue its policy agenda is significantly influenced by the number of "veto players" in a given institutional setting (Tsebelis 1995). As we will see in the next section, the Bundesrat certainly became an important venue for a number of immigration initiatives.

The second reason for the high degree of cooperation is that the implementation (i.e. execution and administration) of any federal law is formally handled by the Länder (Art. 30 and 83 GG). Naturally, the Länder also administer state-exclusive laws. Although there are many avenues of federal involvement and control, this division of labour has traditionally left the German states with a wide scope of discretion and power beyond mere procedural interpretation. Furthermore, formal and informal cooperation between states at the intergovernmental level is the norm. A frequently cited reason for this extensive coordination is a commitment to uphold "similar living conditions" in all states (Benz 2000, p. 24). Depending on the issue, states may ratify formal agreements or contracts with one another. They may also meet ad hoc or at regular intervals at conferences or in commissions. For instance, all state prime ministers get together regularly. Similar events may involve certain types of ministries only. Frequently, though not always, federal counterparts are included. An important example of the latter that has been very influential regarding migration is the standing conference of the Ministers of the Interior (Innenministerkonferenz, IMK), ${ }^{3}$ which has been meeting at least twice a year since 1954. The rise of the IMK to perhaps one of the most important decision making bodies in immigration is particularly noteworthy, as it underlines the upwards shifting of responsibility to the intergovernmental level.

${ }^{3}$ See: http://www.bundesrat.de/cln_051/nn_8758/DE/gremienkonf/fachministerkonf/imk/imk-node. html. 
Third, Länder powers are tempered by the fiscal reality of German federalism. With most taxation power residing exclusively with the "federation" (Bund), what little such power the Länder possess is largely exercised at the local level (Art. 105 $\mathrm{GG})$. The constitution further lays out a complex equalization system. For one, it designates revenues from certain taxes exclusively to the states. It also provides for equalization payments among the Länder and provides for further transfers from the federation and within each Land if necessary (Art. 106 para. 7 GG). Still, the overall set-up privileges the federation because states cannot have a say in financial policymaking without forging alliances at the Bundesrat. Although they can experiment and innovate when implementing policy to a certain degree, they cannot experiment with new revenue sources, which naturally constrains their options (Gunlicks 2003, p. 191). These financial realities also impacted immigration negotiations in the area of asylum, as we will see shortly.

The fourth reason for the high degree of cooperation in the German system is that the federal government can expand its scope of influence substantially and with little consent of the Länder by creating federal agencies or advisory bodies in areas of Länder jurisdiction. Although one such agency, the Federal Office for Migration and Refugees (Bundesanstalt für Migration und Flüchtlinge, BAMF), certainly exudes a substantial degree of influence and saw its authority expanded with the 2005 Migration Act (Zuwanderungsgesetz), it was technically created in an area of concurrent jurisdiction. The Länder have fewer options for acting alone. Although the 2006 and 2009 federalism reforms somewhat strengthened their position, their overall ability to act alone is fairly limited, even for those Länder in which the issue of migration is more pressing, be that for partisan political reasons or because of settlement patterns (Blumenthal 2012). While local governments only generate some of their own revenues and are ultimately financially dependent on revenue transfers from their respective Land, they have made full use of their policy manoeuvring room, leading the way when it comes to immigrant integration, although not always to the benefit of migrants.

So, how can changes within this type of federal system occur? In other words what are possible mechanisms towards devolution or centralization? As Blumenthal notes (Blumenthal 2012), the first involves a formal change to the division of powers as laid out in the Basic Law. This requires a constitutional amendment, which is only possible with the consent of 2/3 of the Länder. The most recent examples are the 2006 and 2009 federalism reforms; however they only affected migration tangentially. The second entails the tightening (or expansion) of the scope of discretion built into one of the federal laws, which the Länder are tasked to implement. While a tightening would have to be mandated in federal legislation, an expansion can occur quite simply through Länder-specific interpretation or the increased use of intergovernmental fora. As we will see in the next section, this has been the most frequent mode of change in German immigration federalism. However, whether this constitutes "devolution" is another question. This would imply a more permanent shift of responsibility from the central to the subnational level. Here, it is merely the Länder making use of what they were already granted. Moreover, as already mentioned, we can observe an increasing tendency towards centralizing lately. Upon closer inspection, we will see that this in fact an oscillating develop- 
ment, which shows that we need to analyze these changes over time, i.e. by identifying distinct phases.

The interaction and coordination of federal and subnational actors in Germany takes place within a larger model of governance at the national and EU level. Briefly, in the national, "semi-sovereign" model, a range of decentralized yet powerful state actors, ranging from the Länder to the Chancellor and the Constitutional Court, constantly negotiate with a set of highly centralized societal (or "parapublic") organizations, such as churches, labour and employer associations, leading to, at best, incremental policy change over the years (Katzenstein 1987). This national model, as Green has shown, explains the overall incremental nature of migration policy making in Germany very well (Green 2004).

While this general model emphasizes the internal constraints affecting policy making within Germany, immigration regulation in Germany also needs to be understood with external constraints in mind, in particular, with respect to the evergrowing significance of the European Union (EU). EU integration has created a complex system of "multi-level governance," with additional rules, layers and networks that political actors must navigate to achieve their policy preferences (Marks et al. 1996). The term "multi-level governance" underlines that no single actor has the power to dominate the agenda. Conflicts are resolved through coordination and negotiation. Unlike the traditional German system, however, the EU system is less likely to result in stalemates (Benz 2000, p. 21). In the area of migration, EU regulations are slowly beginning to affect everything from the minimum standards of reception conditions for asylum seekers to the entry and residence of highly qualified workers. ${ }^{4}$

All in all, while federalism partly explains Germany's regulatory response to migration, it is embedded in a broader, 'semi-sovereign,' multi-level model of governance that has dominated German politics for decades (Katzenstein 1987). It is this model, increasingly together with EU policy, that more fully explains the regulation of migration in Germany. Although I am unable to fully explore these general models in more detail here, recognizing their impact on Germany's immigration federalism is critical for developing theories that could apply across federations. The next section begins by briefly describing Germany's population make-up and its three migratory "waves" and is followed by the analysis of the four central aspects of immigration policy mentioned earlier: labour migration, asylum, enforcement and integration.

\subsection{Germany: A Reluctant Immigration Nation}

Germany, with 81.8 million inhabitants, is the most populous state in the European Union. Despite its past policy of not considering itself a country of immigration, it now possesses one of Europe's largest migrant communities. Its territory is di-

\footnotetext{
${ }^{4}$ The two examples are: Council Directive 2009/9/EC, January 27, 2003 ("Minimum Standards Directive"), Council Directive 2009/50/EC, May 25, 2009 ("EU Blue Card Directive").
} 
vided into 16 Länder, 5 of which joined with reunification in 1989. For historic reasons, 3 out of the 16 are "city states"-Berlin, Hamburg and Bremen. Roughly 15.7 million, or $19.3 \%$ of the population, have a "migration background." This includes all those who have either migrated to Germany themselves or who are second and third generation descendants, regardless of citizenship status. The largest (non-EU) group is of Turkish background, followed by Russian, Polish and Italian (Bundesamt 2012).

Only a small percentage of migrants (under 5\%) live in the former East - most live in the more populous Western states, North Rhine-Westphalia, Bavaria and Baden-Württemberg (ranging from 10 to over 25\%). Germany's migrants are further predominantly urban, with $80 \%$ living in cities larger than 100,000 inhabitants. The largest German cities (Berlin, Hamburg, Munich, Cologne and Frankfurt; all over 600,000) have attracted significantly more migrants than the mid-size and smaller municipalities, ranging from almost $30 \%$ in Frankfurt to $10 \%$ in Essen (Schmitter Heisler 2008, p. 238). As we will see, cities and local governments have increasingly taken the lead when it comes to integration.

Migration to Germany occurred in three "waves" (Hansen 1999, p. 417). The first spanned the 1950s and 1960s, Germany's postwar economic boom decades, which created such a demand for workers that Germany concluded a number of "guest worker" agreements with Mediterranean countries, ranging from Italy (1955) and Turkey (1961) to Yugoslavia (1968). The 1973 oil crisis slowed down the dramatic economic growth and lead to a formal stop in such recruitment-not just in Germany but in other EU countries that had similar labour agreements, such as France, Switzerland and the Netherlands (Messina 2007). The next wave occurred during the 1970s and 80s and consisted largely of family reunification despite the German government's attempts to discourage the practice and instead encourage repatriation (or "rotation"). The third wave, peaking during the 1980s and 1990s, consisted of asylum seekers, who - fuelled by numerous civil wars-entered Germany relying on a unique, asylum provision in the German constitution (Art. 16 GG) - which was not amended until 1993, making Germany (one of) the top EU refugee-receiving countries at the time. ${ }^{5}$ Moreover, based on Art. 116 GG, individuals (largely from Eastern Europe and the former Soviet Union) able to demonstrate German "ethnic" origin either as "expellees" (Vertriebene) or as "re-settlers" (Aussiedler), have entered Germany in large numbers throughout the postwar era, peaking at an unprecedented 400,000 in 1990. Since 2000, their intake has been limited to 100,000 annually and since 2005, resettlement further requires evidence of basic German language proficiency. More recently, Germany has seen a moderate influx of migrants, largely through changes in EU regulations.

\footnotetext{
${ }^{5}$ See http://www.unhcr.org/pages/49c3646c4d6.html for historical data.
} 


\subsection{Labour Migration}

Although it was the federal government, albeit in consultation with major industry, that formally concluded the well-known "guest worker" treaties in the 1950s and 1960s, this power to admit — which is often considered the most important in immigration matters - diminished in significance once the federal government decided to formally end guest worker recruitment with the 1973 oil crisis. At the same time, Länder prominence rose because the (federal) 1965 Foreigner Act (Ausländergesetz, AuslG) - which was fundamentally revised in 1990 and replaced by the 2005 Residency Act (Aufenthalts $G$ ) - contained only broad guidelines and assigned almost complete discretion to the states when it came to the issuing (and denying) of residency permits to foreign nationals. This was not unusual but rather in keeping with the constitutional principle that regulating the status of foreigners is a "shared responsibility." However, it underlines that in Germany, experiments with the marketization of immigrants took place early on and that in this early, post-war period, subnational actors were already substantially involved in defining (and limiting) membership. As we will see later, this principle of shared responsibility has granted states an equally wide scope of discretion in enforcement matters, such as deportation and detention.

As Green points out, prior to 1965 , the discretion of state officials was fairly limited in that a residency permit had to be granted to a foreigner once their "worthiness" to reside in Germany had been established. The 1965 AuslG shifted the power to grant such permits to local officials by decreeing that residency permits could be issued if the presence of the foreigner did not contravene the "interests of the state." The latter was left completely undefined in federal law-even in secondary regulations. Moreover, initially federal legislation did not impose any time limitations on residency permits and most importantly, made no mention of a process for family reunification. What early regulations did make clear was that permits were to be granted only for a limited period of time (e.g. initially 1 year) and that they should be denied if there were any doubts regarding alignment of the would-be immigrant with the state's interests. These guidelines were in keeping with Germany's restrictive, federal naturalization laws and its initial "not a country of immigration" position (Green 2004). However, they were not followed and subsequently engendered a federal-subnational "conversation" about the limits of membership and in particular, the right to stay.

The local level grew in importance because the actual issuing (and denying) of residency permits occurs in "foreigner" offices (Ausländer Amt or Ausländer Behörde) located at the municipal level. Although they follow Länder-wide regulations, the individual officers are the ones tasked with interpreting these regulations. Not surprisingly, studies found a wide variety of permit granting practices across the country. Although some have argued that past practice largely followed partisan lines (i.e. more restrictionist in the more conservative states in the South) (Joppke 1999), others have shown that there is a considerable degree of variation between larger cities and smaller municipalities even in conservative states, like Bavaria, casting some doubt on the generalizability of this finding (Ireland 2004). 
While the role of the subnational level in the issuing of residency permitshowever discretionary and restrictive - is part of their traditional constitutional mandate of policy implementation, what is perhaps more surprising is that states have also been prominently involved in policy making at the federal level. Recall that their participation may occur through the larger "interlocking" framework of German federalism, which grants a significant role (though not necessarily power and success) to states in federal policymaking, both formally through the Bundesrat and informally through intergovernmentalism. For states to successfully influence federal policymaking, they need to either form coalitions with one another or cooperate with an influential federal actor, such as the Ministry of the Interior. As the following, well-known examples show, while the federal government's past policy making style with respect to foreigners has usually been characterized as reactive and incremental, the Länder have been much more willing to go out on a limb by pushing forward with their own policy initiatives. These initiatives have often been restrictive in nature.

A rotation of workers was critical to Germany's guest worker programs prior to the 1973 recruitment stop but, as was widely documented, this was never realized. For one, the federal government was reluctant to enforce rotations. As already mentioned, it was initially equally unwilling to legislate time limits for residency permits. Therefore, workers - with the backing of employers and home countriesoften stayed longer than initially envisaged and also brought their families. For instance, a 1964 revision to the recruitment agreement with Turkey lacked both a maximum stay and a prohibition to family reunification (Triadafilopoulos and Schönwälder 2006, p. 8). Thus, de facto settlement was occurring and the commitment to marketization was slipping.

It was ultimately the states that repeatedly pushed for instituting and enforcing limits on residency permits and family reunification, which (so was the thinking at the time) would encourage rotation and affirm Germany's policy of not being a country of immigration. Their first effort occurred in 1965, at the same time as the new Foreigner Act was finally passed. The standing conference of the Ministers of the Interior (Innenministerkonferenz, IMK) ${ }^{6}$ which includes the federal Minister, released a draft set of "foreigner policy principles" consisting, among other things, of a strict, 3-year limit on residency permits (Schönwälder 2003, p. 130). As part of a grand political compromise, this particular limitation was eventually dropped. However, a subsequent, Bavarian-lead initiative in 1969 successfully instituted a policy that would limit residency permits to 5 years (Triadafilopoulos and Schönwälder 2006, pp. 10-11). Still, when Bavaria and Schleswig-Holstein began issuing deportation letters in late 1972, they faced such significant opposition that the federal government publicly proclaimed that "no legal instruments" would be used to enforce the limits imposed, effectively forgoing rotation from then on (Schönwälder 2003, pp. 136-137).

\footnotetext{
${ }^{6}$ See http://www.bundesrat.de/cln_051/nn_8758/DE/gremienkonf/fachministerkonf/imk/imk-node. html.
} 
Imposing restrictions on family reunification had also been part of these statelevel proposals but little progress had been made. In the fall of 1981, almost a decade after the official 1973 recruitment stop, the CDU-ruled states unilaterally announced tough family reunification restrictions, which (among others) excluded children above the age of 16 from joining their parents in Germany and required that both parents reside there. They also introduced restrictions on circumstances under which spouses could emigrate. These restrictions came on the heels of a lot of "noise," i.e. policy announcements at the federal level without subsequent legislation (Green 2004, pp. 44-45). However, once the (then SPD-led) federal government was confronted with the (CDU-lead) state-level restrictions, it unilaterally drafted a set of "guidelines" that mirrored the relatively tough restrictions of the state of Berlin, leaving other states, including Bavaria, little choice but to fall in line. Nevertheless, these guidelines were not binding and some variation persisted since some states refused to budge on certain points. That was not the end of the story. In 1982, a federal CDU/CSU-FDP coalition was elected. Although it took up the cause of reforming family reunification with a vengeance, it too did not successfully pass any legislation until almost 10 years later, in 1990. Most analysts note that even then it merely codified what had already been the policy on the books, due, inter alia to a number of important constitutional court cases on the topic (Joppke 1999).

Finally, the 2005 migration act and subsequent 2009 regulations simplified the granting of residency permits by reducing the number of categories and the degree of discretion available to subnational actors. These regulations reflect a broader, renewed willingness at the federal level to take the lead on immigration questions, albeit in consultation with other political actors. They also denote a strong centralizing tendency in this area for the first time in decades.

\subsection{Asylum}

At first glance, it seems that asylum policy in Germany is primarily a federal responsibility. Broad, federal legislation, beginning with the 1953 asylum regulations (Asylverordnung, AsylVO) — together with Germany's constitutional asylum provision (which was restricted in 1993) - governs refugee determinations. Moreover, the Federal Office for Refugees, since 2005 known as the BAMF, was put in charge of all decisions regarding refugee status as early as 1953 and is overseen by federal courts. However, federal laws and regulations were only updated infrequently over the decades and primarily focused on establishing procedural "how to" guidelines instead of addressing substantive questions, effectively leaving policy development to the Federal Office together with the Bundesbeauftragter, the representative of the Federal Ministry of the Interior until 2004 as well as the federal courts (Korbmacher 1987). More recently, federal legislation and guidelines have increased and among other things, brought Germany's refugee determinations in line with that of other countries, for instance by accepting non-state and gender-based persecutions. 
So what is role of the states in refugee policy? And more importantly, when and how has this role changed? Although one might assume that the states would be primarily responsible for the reception and settlement of refugees (e.g. housing and feeding) and exercise their discretion there, it is precisely this settlement role that has also led to a "feedback loop," i.e. an assertion of their influence in policymaking at the federal level. More specifically, the financial and social pressures of housing refugees in local communities have served as an incentive for states to exert pressure on federal policy through the Bundesrat. Overall, the Länder have been a restrictive force in asylum policy making, although there certainly is substantial variation in their positions (Thränhardt 2001, pp. 20-21).

A central motivation for their involvement in federal policy making is Germany's asylum dispersion policy. Incoming refugees were initially housed and processed in a reception facility in Bavaria. The drastic increase in refugee numbers in the mid 1970s eventually made the continuance of this arrangement unworkable. Since 1974, asylum seekers have been dispersed to reception facilities across all German states shortly after their arrival (Boswell 2003, pp. 318-319). The number of refugees per state is kept proportionate to the population in each state. Each state's tax revenues are also considered when calculating the number of refugees per state. Within each state, refugees are then further distributed among the various cities and municipalities.

Under the current scheme, which was finally codified in 1982, however, states carry the reception costs exclusively and do not receive any further reimbursement from the central government. Although this kind of cost sharing is typical for Germany's federalism, it increases the financial pressure on the states, which are also responsible for providing social assistance. This pressure was particularly intense between 1978 and 1989 when the number of asylum seekers entering Germany rose dramatically. As a consequence, individual states, in particular Bavaria, BadenWürttemberg and Berlin, who were receiving particularly large numbers of refugees from the East (Fullerton 1988), started to public campaign for a tightening of asylum laws citing the intense pressure of accommodating "merely economic" refugees on the public purse as a reason (Schuster 2003, pp. 199-204) To deal with the spiking numbers, successive federal governments passed a number of laws between 1978 and 1988 intended to curb the number of asylum seekers by "accelerating" the refugee determination process. Concurrent legislation in the 1980s also reduced social assistance benefits to refugees and introduced a residency requirement for asylum seekers (in the municipality of their reception centre). Clearly, federalizing the reception of asylum seekers was also intended as a deterrent to refugees and as a mechanism to limit their membership rights (Boswell 2003, p. 319).

While all states had pressured the federal government for changes to the refugee determination procedures, the last bill during this period in 1987 is worth mentioning separately here. It was introduced in the Bundesrat by the same state "troika" that had publicly campaigned for tighter asylum rules a few years earlier (Schuster 2003, p. 202). Among other things, it proposed "in kind" rather than cash payments for refugees, increasing the waiting period for work permits from 2 to 5 years, ${ }^{7}$

${ }^{7}$ Applicants from Eastern Europe had to wait only 1 year (Kanstroom 1993, p. 197). 
and expanding the category of "manifestly unfounded" claims, which came with (and still does) tightened appeal options and increased the likelihood of deportation (Fullerton 1988, pp. 67-70). Although some measures were left out in the course of negotiations, the core of the bill ultimately became law, underlining the influence of the Länder in limiting noncitizen rights.

The dispersal policy brought with it financial tensions that percolated up the federalism chain in the form of pressure for policy change. After reunification, it also raised social conflicts at the local level to new heights, in particular in the new German states. Violent attacks on asylum seeker reception centres in Hoyerswerda and Rostock but also on foreign nationals in Mölln and Solingen between 1991 and 1993, put pressure on politicians to change policies more drastically, culminating in the tightening of the constitutional asylum provision in 1993. At the same time, a range of provisions aimed at increasing "burden" sharing with other EU countries were introduced. The constitutional amendment necessary for these changes required a 2/3 majority in both houses. Hence, this "asylum compromise," as it is often called, could only be reached in true German fashion, namely after wide reaching negotiations and compromising with other political and societal actors. Among the successfully bargained items were the introduction of an annual limit on the number of ethnic Germans allowed to relocate to Germany (200,000 in 1990 and 100,000 in 2000), a promise to open up the definition of refugee to include those fleeing civil wars and a commitment to reform German citizenship and naturalization laws (Schuster 2003). Despite recent protests, the dispersion policy remains in place to date. However, with the passing of the EU's "minimal reception standards" directive, the EU is also making its influence known in this area.

\subsection{Enforcement and "Toleration"}

Immigration enforcement, which usually encompasses a range of practices from detention to deportation and expulsion that are aimed at an individual's removal from the country, is intimately connected with the regulation of the residency status of foreign nationals, which is an area of shared jurisdiction. Germany's practice of "tolerating" individuals whose removal orders have been temporarily stayedoften for years - without granting them a residency permit will also be discussed briefly, because it is another example that illustrates the rise of the IMK to one of Germany's central immigration policy making venues. These enforcement practices further highlight both the influence of Germany's interlocking federalism on the governance of immigration and the ease with which a deliberate shift in policy venues can occur.

Enforcement practices are "constitutive of citizenship" in that they not only "reaffirm the legal boundaries of membership" but also showcase the state's "raw" sovereign, disciplinary power (Anderson et al. 2011). Paradoxically, for a long time this power was of secondary importance because it came with too many, costly and time consuming constraints (Gibney 2008). This was reflected in decades of relatively low deportation figures. However, in the mid 1990s, Germa- 
ny's removal numbers spiked dramatically, as did those of other liberal democracies (Ellermann 2009, p. 19). Although deportation can affect any foreign national without status, this particular "deportation turn" was caused by a drastic increase in the removal of rejected asylum seekers, who were targeted as a result of the growing securitization and politicization of "illegal" migration (Gibney 2008, p. 146). Over the same time, the number of asylum seekers coming to Germany started decreasing. However, since 2000, unlike in the UK and the US, deportation numbers in Germany have started dropping back to 1990 levels again (Anderson et al. 2011, p. 551).

Responsibility for deportations and detentions has always been shared between the federal and the subnational level, illustrating yet again that control over the definition of membership in Germany was never an exclusively federal affair. Both, the Federal and the Länder Ministry of the Interior issue key regulations and (since 2005) can directly issue a limited number of deportation orders. ${ }^{8}$ Deportation orders for rejected asylum seekers are generally issued by the BAMF but carried out by local foreigner offices, discussed earlier, in conjunction with the police. If a deportation is carried out by air, federal police agents are in charge (since 2004, increasingly in collaboration with Frontex, the EU's border agency), while regional and local police officers are responsible for local arrests. Foreigner offices are further responsible for issuing deportation orders in other cases (e.g. for illegal or resident aliens convicted of a criminal offense), and if necessary, requesting detention orders from a local court.

Yet this discretion and local grounding has also made the foreigner offices open to anti-deportation campaigns by local churches, refugee councils and human rights activists. For instance, between 1983 and 2000, church sanctuary campaigns (Kirchenasyl) resulted in roughly 70 percent of 2,500 cases being granted at least a more favourable legal status, if not a residency permit (Castaneda 2010, p. 252). At the same time as such local activism grew, state governments shifted the responsibility for carrying out deportations "up" from the local to the regional level (Ellermann 2009). Baden-Württemberg led the way. In 1989, it established four regional immigration authorities that took over responsibility from 120 local offices. It also reorganized accountability, so that the regional offices are no longer overseen by elected officials (i.e. mayors) but by appointed bureaucrats, which significantly reduces their exposure to political influence by anti-deportation advocates. However, not all German states have followed Baden-Württemberg's lead. Some, like Brandenburg, even explicitly rejected such reorganization after testing it (Ellermann 2009, p. 127). While Ellermann's study underlines the nimbleness of political and bureaucratic arrangements at the subnational level, it further shows that these reorganizations did not consistently follow partisan lines, suggesting that these upward and downward shifts are not exclusively driven by ideology but inadvertently perhaps by the success of mobilization efforts on the ground.

In Germany, the practice of staying deportation orders, frequently for long periods of time and often for entire groups of non-citizens, together with the granting of a special "tolerated" permits ("Duldung"), needs to be discussed here as well. Since

\footnotetext{
${ }^{8}$ In cases of "particular federal interest" or in case of a danger to national security or of terrorism (Par. 58 a AufenthG).
} 
a toleration permit is intended to be temporary, it does not come with some core membership rights, such as a certain welfare provisions or a work permit, although the latter may be granted in some circumstances. Typically, individual reasons why local officials may stay someone's deportation order are illness, pregnancy or other evidence of "deservingness" (Castaneda 2010). Since 2009, some individuals on such a permit, for example young adults, who are judged "well integrated," may be granted a residency permit (Par. 25a AufenthG).

The practice of merely tolerating someone, without granting them some kind of firm status to remain, has attracted significant political debate. More importantly for our purposes, with time, its function as a discretionary enforcement tool at the local level has almost become completely overshadowed by its significance as a policymaking instrument at the Länder, intergovernmental, and more recently, federal level. Specifically the IMK, along with some Länder, have repeatedly granted large-scale amnesties from deportation, or at least long-term exemptions, to rejected refugees and others without status. For instance, the IMK stayed the deportation orders of rejected refugees from Eastern Europe in a wholesale fashion in 1966 (Höfling-Semnar 1995, p. 114) and has done so regularly for various groups since, most recently for rejected refugees from Afghanistan and the former Yugoslavia. Interestingly, both the IMK and some Länder governments have been open to lobbying by employers (Schönwälder 2003), illustrating that these actors are not only charged with defining membership but also with adjudicating demands for labour.

While reforms in 2005 further institutionalized the policymaking aspect of the Duldung, by mandating that all Länder create a hardship commission for assessing whether someone's deportation order should be stayed, they also removed discretion from the Länder by mandating the agreement of the Federal Minister of the Interior to any large scale stays, leaving the Länder with significantly less political manoeuvring room than previously. Interestingly, this change passed only after extensive consultation and ultimately, with consent of the Länder, in anticipation of a new EU regulation adopted in 2008 on the return of third country nationals (Blumenthal 2012). ${ }^{9}$ Still, Duldung stands out as yet another important example of the expanded significance of subnational control over the regulation of migration, rights and membership in Germany.

\subsection{Cities, Local Governments and Integration}

In the introduction to their 2012 annual report, the expert council on migration (Sachverständigenrat deutscher Stiftungen für Integration und Migration $)^{10}$ repeated a core message of an earlier report: "Germany has arrived in the integration society age. Integration in Germany is better than its reputation" (Migration 2012, p. 7). Yet the fact that Germany has arrived there at all is primarily due to leadership at the subnational level and has occurred largely in the absence of any acceptance of the permanence

\footnotetext{
${ }^{9}$ This is EU Directive 2008/115, the so-called "Returns Directive."

${ }^{10} \mathrm{http}: / /$ www.svr-migration.de/content/.
} 
of immigration at the federal level. As Penninx et. al. note: "As a consequence of non-acceptant European attitudes, immigrant integration polices at the national level have generally been late to develop, if they have been developed at all (Penninx et al. 2004, p. 3)."

Given Germany's long-standing reluctance to consider itself a country of immigration, how then did the presence of migrants become a political issue at the subnational level and when did dealing with this "presence" turn into a commitment to integration (Mahnig 2004)? And what does this development tell us about shifts in immigration federalism? And what role do local actors exactly play in integration? Consulting Germany's formal division of powers for an answer offers little help. Although the subnational level is exclusively responsible for culture and education - two important areas that facilitate immigrant participation, inclusion and social mobility - even these two policy areas are subject to a complex web of federal coregulation and participation. For instance, while the hotly debated topic of religious instruction in schools (which is mandated in the German constitution (Art. 7(3) GG)) is overseen by state-level ministries in coordination with religious communities, Germany's extensive apprenticeship programs are governed by both federal and statelevel regulations. Other components of integration, ranging from social housing and welfare provisions to language courses and even naturalizations are equally governed by both federal and state-level regulations and implementation. The local level thus has precious little policy-making power of its own, but plays a central role in deciding how and where something gets implemented and whether the growing diversity of German cities is taken into account when doing so, ranging from early childhood initiatives for non-native speakers to support for ethnic festivals and the creation of anti-discrimination guidelines. Noteworthy, yet still understudied, is the involvement of other local actors in the integration process, including local churches, businesses, voluntary organizations and increasingly, immigrant organizations (Mushaben 2008). Ultimately, the local level is the critical juncture between noncitizens and their rights.

Although the "reality" of immigration hit home sooner in the cities, there is currently no agreement on how cities and municipalities became the lead actors in German integration politics. Scholars point to both "top-down initiatives by political elites, aimed at preserving their own control," and to local crisis, such as "urban unrest" not to mention "closed door commitments of civil servants and judges," as motivating policymakers, albeit less so "bottom up" pressures (Mahnig 2004, pp. 17-18). All in all, local policies have not necessarily always been migrant friendly. Nevertheless, faced with inaction, silence and incrementalism at the national level, local actors have not been afraid to experiment and shown a great deal of leadership.

The cases of Berlin and Frankfurt show that partisanship at the local level played an important role in the basic openness of local policy makers. Under successive conservative governments, Berlin, one of the most frequently studied German cities when it comes to integration, initially pursued a very restrictive migrant policy during the 1970s and early 1980s, that included barring migrants from living in certain districts and confining them to others while advocating for returns and restrictive admissions at the federal level (even under SPD). Although it committed itself more firmly to integration in the mid 1980s, it still continued to talk tough to its electorate while expanding integration initiatives on the ground. Only under the red-green 
coalition did it finally shift to framing its integration discourse in a language of equality and anti-discrimination (Mahnig 2004, pp. 24-25).

In Frankfurt, the city known as Germany's financial capital, a prominent Green party city counselor, Daniel Cohn-Bendit, led the city to open Germany's first ever "Office of multicultural affairs" $(A M K A)$ as one of its many administrative units (Aybek 2010, p. 95) in 1989. This occurred without the backing of "bigger" political players and was highly controversial at the time (Amt für Multikuturelle Angelegenheiten 2009, pp. 10-16). What made the office unique was that it gradually expanded its sphere of influence and also, its budget, while acting as a central coordination unit for a range of integration projects. Most importantly, it was intended to facilitate a paradigm shift towards integration, a step that other actors in the federation were only reluctant to accept (Amt für Multikuturelle Angelegenheiten 2009, p. 10). Today, the AMKA is involved in a wide variety of projects from support for early childhood education to vocational training and neighbourhood conflict monitoring. ${ }^{11}$

Finally, although the granting of citizenship falls under federal jurisdiction, the actual overseeing of naturalizations, another core measure of integration, has always been a responsibility of the Länder. Naturalization used to be a rare act administered by the local foreigner offices, because the requirements were high (minimum 15 year residence, no dual citizenship allowed, proof of a firm "orientation towards Germany," administrative fees etc.) and because the officers retained a substantial degree of discretion in the interpretation of the (federal) regulations (Green 2004, p. 40). Reforms in 2000 resulted in a flurry of state-level initiatives, and a set of questions that were meant to guide the decision of local foreigner offices morphed into a "citizenship test" requirement, that was subsequently standardized and enshrined in federal legislation in 2008.

While the many initiatives and experiments at the local level certainly underline the local level's ability, given sufficient resources and policy freedom, to serve as "laboratories of innovation," they could equally prove the "steam-valve" theory, which views localities as relief points for bad ideas in a federal system (Provine and Varsanyi 2012, p. 107). Further research is needed to uncover the mechanisms and transferability of effective integration policy. What is clear is that national policies, images and institutional arrangements matter a great deal because they channel opportunities and provide important symbolic and actual endorsement for approaches to integration (Penninx et al. 2004). The German federal level has certainly begun to reassert and reorient itself when it comes to immigration and integration. Beginning with the cautious opening of its citizenship laws in 1999 towards the ius soli principle (i.e. citizenship based on place of birth instead of descent), followed by the passing of a new Migration Act in 2005 (which included, for instance, the publication of an annual national integration plan and the mandating of integration and naturalization courses), it has firmly shifted the national debate towards integration as well. While some observers view the current German debates on integration as in line with a larger EU shift towards hard line "civic integrationism," this shift comes after decades of denial and neglect at the federal level.

${ }^{11}$ http://www.frankfurt.de/sixcms/detail.php?id=7017\&_ffmpar[_id_inhalt] $=7846492$. 


\subsection{Conclusion: The Janus Face of Germany's Immigration Federalism}

This brief survey of Germany's immigration federalism has shown that the particular federalism model in place there ultimately facilitated both the restriction and expansion of non-citizen rights. Unlike in other federations, subnational actors played important roles early on in the regulation of all aspects of German migration, ranging from labour migration and asylum to enforcement and integration. However, their role in these areas expanded not because of a formal devolution of federal responsibilities to the subnational level but largely because subnational actors made full use of their powers while the federal government dragged its feet. Still, this had the effect of shifting the control over membership to the subnational and the intergovernmental level (i.e. to the IMK) for decades. Moreover, the high degree of policy initiatives and policymaking at the subnational level frequently created a "feedback loop" at the federal level, in that subnational activities became the basis for federal legislation later on, often together with "input" from the courts. Here, the governance of immigration follows the larger German logic of federalism, which is based on a complex web of coordination, inter-connections and joint decision-making.

The survey further suggests that we should consider conceptualizing any shifts in a country's immigration federalism as "phases" rather than permanent trends. Germany, after all, was one of the earliest users of a classic marketization scheme for immigration, the guest worker programs. Although past choices can significantly influence future decision-making, the most recent flurry of activities at the federal level certainly makes it clear that Germany has entered a new centralization phase. However, this centralization phase, as this chapter has argued, is only another side of a neoliberal nation-state reconstituting itself. This phase is further propelled by the steady increase in EU Directives, regulations, jurisprudence, working groups and other policy-related "output." Although this growth in EU activities has also had the effect of restricting the sovereign policy choices of national governments, the associated regulations seems to have largely "trickled down" to the German subnational level in the form of policy centralization, as the implementation of the recent EU "Returns Directive" illustrates.

Given the nature of Germany's "interlocking" federal system, which is further embedded in a larger system of multi-level "semi-sovereign" governance, this centralization phase will not mean the end of subnational activism and policy leadership. In fact, it serves as a reminder of the range of "venues" available to nation states in this age of global migration.

Acknowledgements I would like to thank Sasha Baglay, Delphine Nakache and Rob Mauchel for their patience and editorial feedback. I also owe sincere thanks to Virginie Guiraudon, Erin Fielding Delaney and Galya Ruffer for their questions and thoughtful comments. 


\section{References}

Amt für Multikulturelle Angelegenheiten, Stadt Frankfurt am Main (2009). 20 Jahre AMKA. Frankfurt, Main.

Anderson, B., Gibney, M., \& Paoletti, E. (2011). Citizenship, deportation and the boundaries of belonging. Citizenship Studies, 15(5), 547-563.

Aybek, C. (2010). Young immigrants' low participation in the german vocational training system: How local actors in Munich and Frankfurt/Main try to make a difference. In T. Caponio \& M. Borkert (Eds.), The local dimension of migration policymaking (pp. 85-107, IMISCOE Reports). Amsterdam: Amsterdam University Press.

Bendel, P., \& Sturm, R. (2010). Federal Republic of Germany. In L. Moreno \& C. Colino (Eds.), Diversity and unity in federal countries (pp. 167-199, A Global Dialogue on Federalism, Vol. 7). Montreal: McGill-Queen's.

Benz, A. (2000). Two types of multi-level governance: Intergovernmental relations in Germany and EU regional policy. Regional \& Federal Studies, 10(3), 21-44.

Blumenthal, J. von (2012). Migrationspolitik nach der Föderalismusreform: Zentralisierung und Dezentralisierung im deutschen Mehrebenensystem. In E. Z. für Föderalismus-Forschung (Ed.). Jahrbuch des Föderalismus 2012: Föderalismus, Subsidiarität und Regionen in Europa (pp. 125-137). Baden-Baden: Nomos.

Boswell, C. (2003). Burden-sharing in the European Union: Lessons from the German and UK experience. Journal of Refugee Studies, 16(3), 316-335.

Bundesamt, Statistisches (2012). Bevölkerung mit Migrationshintergrund-Ergebnisse des Mikrozensus 2011 Bevölkerung und Erwerbstätigkeit. Wiesbaden.

Castaneda, H. (2010). Deportation deferred: "Illegality," Visibility and recognition in contemporary Germany. In N. De Genova \& N. Peutz (Eds.), The deportation regime: Sovereignty, space and the freedom of movement (pp. 245-261). Durham: Duke University Press.

Ellermann, A. (2009). States against migrants: Deportation in Germany and the United States. Cambridge: Cambridge University Press.

Erk, J. (2008). Explaining federalism: State, society and congruence in Austria, Belgium, Canada, Germany and Switzerland. London: Routledge.

Fullerton, M. (1988). Restricting the flow of asylum-seekers in Belgium, Denmark, the Federal Republic of Germany, and the Netherlands: New challenges to the Geneva Convention relating to the status of refugees and the European convention on human rights. Virginia Journal of International Law, 29(33), 35.

Gibney, M. J. (2008). Asylum and the expansion of deportation in the United Kingdom. Government and Opposition, 43(2), 146-167.

Green, S. (2004). The politics of exclusion: Institutions and immigration policy in contemporary Germany. Manchester: Manchester University Press.

Guiraudon, V. (2000). European integration and migration policy: Vertical policy-making as venue shopping. Journal of Common Market Studies, 38(2), 251-271.

Gunlicks, A. (2003). The Länder and German federalism. Manchester: Manchester University Press.

Hansen, R. (1999). Migration, citizenship and race in Europe: Between incorporation and inclusion. European Journal of Political Research, 35, 415-444.

Höfling-Semnar, B. (1995). Flucht und Deutsche Asylpolitik: Von der Krise des Asylrechts zur Perfektionierung der Zugangsverhinderung. Münster: Verlag Westfälisches Dampfboot.

Ireland, P. R. (2004). Becoming Europe: Immigration, integration and the welfare state. Pittsburgh: University of Pittsburgh Press.

Joppke, C. (1999). Immigration and the nation-state: The United States, Germany and Great Britain. Oxford: Oxford University Press.

Kanstroom, D. (1993). Wer sind Wir Wieder? Laws of Asylum, Immigration, and Citizenship in the Struggle for the Soul of the New Germany. Yale Journal of International Law, 18, 155.

Katzenstein, P. (1987). Policy and politics in West Germany: The growth of a semisovereign state. Philadelphia: Temple University Press. 
Korbmacher, H. (1987). Besteht auf dem Gebiet des Asyl- und Flüchtlingsrechts ein Bedarf an gesetzlicher Regelung? In W. Fürst (Ed.), Festschrift für Wolfgang Zeidler (pp. 901-918). Berlin: de Gruyter.

Mahnig, H. (2004). The politics of minority-majority relations: How immigrant policies developed in Paris, Berlin and Zurich. In R. Penninx, K. Kraal, M. Martiniello, \& S. Vertovec (Eds.), Citizenship in European Cities: Immigrants, Local Politics and Integration Policies (pp. 17-37). Aldershot: Ashgate.

Marks, G., Hooghe, L., \& Blank, K. (1996). European integration since the 1980s. State-centric versus multi-level governance. Journal of Common Market Studies, 34(3), 341-378.

Messina, A. (2007). The logics and politics of post-WWII migration to Europe. Cambridge: Cambridge University Press.

Migration, Sachverständigenrat deutscher Stiftungen für Integration und Migration. (2012). Integration im föderalen System: Bund, Länder und die Rolle der Kommunen. Jahresgutachten 2012 mit Integrationsbarometer. Berlin.

Motomura, H. (1994). Immigration, alienage, federalism and proposition 187. Virginia Journal of International Law, 35, 201-216.

Mushaben, J. M. (2008). The changing faces of citizenship: Social integration and political mobilization among ethnic minorities in Germany. New York: Berghahn.

Neuman, G. L. (1996). Strangers to the constitution: Immigrants, borders and fundamental law. Princeton: Princeton University Press.

Oeter, S. (2006). Federal Republic of Germany. In K. Le Roy \& C. Saunders (Eds.), Legislative, executive, and judicial governance in federal countries (pp. 135-164, A Global Dialogue on Federalism, Vol. 3). Montreal: McGill-Queen's.

Penninx, R., Kraal, K., Martiniello, M., \& Vertovec, S. (Eds.). (2004). Citizenship in European cities: Immigrants, Local politics and integration policies (Research in migration and ethnic relations). Aldershot: Ashgate.

Pierson, P. (2004). Politics in time: History, institutions and social analysis. Princeton: Princeton University Press.

Provine, M., \& Varsanyi, M. W. (2012). Scaled down: Perspectives on state and local creation and enforcement of immigration law: Introduction to the special issue of law \& policy. Law \& Policy, 34(2), 105-112.

Scharpf, F. W. (1988). The joint-decision trap: Lessons from German federalism and European integration. Public Administration, 66(Autumn), 239-278.

Schmitter Heisler, B. (2008). Local authority responses to immigrants: The German case. In L. M. Hanley, B. A. Ruble, \& A. M. Garland (Eds.), Immigration and integration in urban communities: Renegotiating the city (pp. 237-267). Washington, D.C.: Woodrow Wilson Centre Press.

Schönwälder, K. (2003). Zukunftsblindheit oder Steuerversagen? Zur Ausländerpolitik der Bundesregierungen der 1960iger und frühen 1970iger Jahre. In J. Oltmer (Ed.), Migration Steuern und Verwalten. Deutschland vom späten 19. Jahrhundert bis zur Gegenwart (pp. 123144). Göttingen: IMIS-Schriften.

Schuster, L. (2003). The use and abuse of political asylum in Britain and Germany. London: Frank Cass.

Shachar, A. (2006). Race for talent: Highly skilled migrants and competitive immigration regimes. New York University Law Review, 81, 148-206.

Spiro, P. J. (2001). Federalism and immigration: Models and trends. International Social Science Journal, 53, 67-73.

Thränhardt, D. (2001). Integrationspolitik in föderalistischen Systemen. In L. Akgün \& D. Thränhardt (Eds.), Integrationspolitik in föderalistischen Systemen. Jahrbuch Migration-Yearbook Migration 2000/2001 (pp. 15-34). Münster: LIT.

Triadafilopoulos, T., \& Schönwälder, K. (2006). How the Federal Republic became an immigration country: Norms, politics and the failure of West Germany's guest worker system. German Politics and Society, 24(80), 1.

Tsebelis, G. (1995). Decision making in political systems: Veto players in presidentialism, parliamentarism, multicameralism and multipartyism. British Journal of Political Science, 25(3), 289-325.

Varsanyi, M. W. (2008). Rescaling the "Alien," rescaled personhood: Neoliberalism, immigration and the state. Annals of the Association of American Geographers, 98(4), 877-896. 